\title{
Fabrication and Evaluation of a New High-Temperature pH Sensor for Use in PWR Nuclear Power Plants
}

\author{
Yongju Jung ${ }^{*}$ and Jei-Won Yeon ${ }^{\dagger, *}$
Department of Applied Chemical Engineering, Korea University of Technology and Education, Cheonan 330-708, Korea ${ }^{*}$ E-mail: yjung@kut.ac.kr
${ }^{\dagger}$ Nuclear Chemistry Research Division, Korea Atomic Energy Research Institute, Daejeon 305-353, Korea
*E-mail: yeonysy@kaeri.re.kr \\ Received July 20, 2010, Accepted August 31, 2010
}

\begin{abstract}
A new high-temperature $\mathrm{pH}$ sensor has been successfully developed by reforming the internal reference systems of the $\mathrm{pH}$ sensors based on oxygen-ion conducting ceramic membrane. The conventional internal reference system, a mixture of $\mathrm{Ni}$ and $\mathrm{NiO}$, has been replaced with partially oxidized $\mathrm{Ni}$ powders, where $\mathrm{Ni}$ and $\mathrm{NiO}$ coexist on the surface of particles, in order to avoid the cumbersome mixing step of $\mathrm{Ni}$ and $\mathrm{NiO}$ particles. The partially oxidized Ni particles were made by oxidizing Ni under air atmosphere at $600{ }^{\circ} \mathrm{C}$ and characterized by X-ray diffraction (XRD) and FTIR spectroscopy. The viability of the $\mathrm{pH}$ sensor developed was assessed in boric acid (1000 ppm-B) / lithium hydroxide ( 1 to $3 \mathrm{ppm}-\mathrm{Li}$ ) buffer solutions at $280^{\circ} \mathrm{C}$. The $\mathrm{pH}$ sensor showed excellent accuracy with a small error less than $\pm 0.2 \mathrm{pH}$ units.
\end{abstract}

Key Words: High-temperature pH sensor

\section{Introduction}

It is of significant importance to control and measure $\mathrm{pH}$ of coolants in pressurized water reactor (PWR) primary system in order to minimize the generation of corrosion products within the primary coolant loop. For the measurements of $\mathrm{pH}$ in hightemperature aqueous systems such as nuclear power plants, four types of $\mathrm{pH}$ sensors have been proposed, including platinumbased hydrogen electrodes, ${ }^{1}$ palladium hydride electrodes, ${ }^{2,3}$ metal/metal oxide electrodes, ${ }^{4,5}$ and ceramic membrane electrodes (e.g., the yttria-stabilized zirconia (YSZ) membrane electrode). ${ }^{6-9}$ In case of hydrogen electrodes, however, it is not easy to practically use them because molecular hydrogen should exist in a test system. ${ }^{10}$ For palladium hydride electrodes, they cannot be used in a system containing oxidants. ${ }^{10}$ Above all, the three systems except ceramic membrane electrodes show a mixed potential in case that electrochemically active species exist in a system. For this reason, they have not been used in the area of nuclear power plants. On the other hand, ceramic membrane electrodes such as YSZ, which can be used under various chemical environments containing other redox species due to oxygen-ion selectivity, have attracted much attention as a reliable sensor for high-temperature $\mathrm{pH}$ measurements. ${ }^{10}$ The YSZ membrane electrodes consist of the following two parts: 1) YSZ membranes that play role of an oxygen-ion conductor and 2) metal $/$ metal oxide internal reference systems (e.g., $\mathrm{Cu} / \mathrm{CuO}$, $\mathrm{Ni} / \mathrm{NiO}, \mathrm{Hg} / \mathrm{HgO})$ inside the $\mathrm{YSZ}$ membrane. The proton $\left(\mathrm{H}^{+}\right)$ activity in the test solutions makes an influence on the oxygen vacancy of the ceramic lattice and finally the equilibrium of the metal $/$ metal oxide systems. So far, metal $/$ metal oxide systems were made through homogeneous mixing of metal and metal oxide particles, which has been considered as a cumbersome and time-consuming process.

In this study, we present a new YSZ membrane-based $\mathrm{pH}$ sensor using partially NiO-coated Ni particles instead of a con- ventional internal reference system, a mixture of $\mathrm{Ni}$ and $\mathrm{NiO}$ particles, in order to simplify manufacturing process and increase reproducibility. The new high-temperature $\mathrm{pH}$ sensor has been constructed by filling YSZ membrane tube with a NiOcoated Ni powders which were made by a simple oxidation method. The surface of Ni powders was oxidized under air atmosphere at $600{ }^{\circ} \mathrm{C}$. The resulting Ni powders were analyzed using X-ray diffraction (XRD) and FTIR spectroscopy. The performance of the $\mathrm{pH}$ sensors was evaluated in aqueous solutions containing LiOH and boric acid at $280^{\circ} \mathrm{C}$, which are a general composition of primary coolant systems. Furthermore, the influence of trace elements (e.g., $\mathrm{Fe}, \mathrm{Ni}, \mathrm{Zn}, \mathrm{Cr}$ ) on $\mathrm{pH}$ of coolant systems was examined at $280{ }^{\circ} \mathrm{C}$.

\section{Experimental}

Once-through loop system for high-temperature pH measurement. Stainless steel (SUS 316) with excellent mechanical properties was used as structural materials for a once-through loop system. To protect the corrosion on stainless steel at hightemperature solutions, the interior of the main body was coated with titanium metal which is considered to be physiologically inert and stable under severe chemical environments. Titanium metal was placed by inserting a titanium tube $(34.8 \mathrm{~mm}$ in inside diameter with a wall thickness of $1.64 \mathrm{~mm}$ ) to the inside of the main body right after a titanium tube was cooled to shrink at a temperature of $-196^{\circ} \mathrm{C}$. For mechanical integrity between titanium tube and SUS 316 body, the main body was heated at $200{ }^{\circ} \mathrm{C}$ for $5 \mathrm{~h}$. The flow rate and pressure of the once-through loop system were controlled by a high-pressure diaphragm pump (Teikoku EKMs-1) and a back-pressure regulator (Tescom 6000 PSIG), respectively. In this study, the loop system was operated with a flow rate of $10 \mathrm{cc} \mathrm{min}^{-1}$ at $120 \mathrm{~atm}$.

Development of a new $\mathrm{pH}$ sensor using partially oxidized $\mathrm{Ni}$ powders. To determine an appropriate oxidation temperature, 
$\mathrm{Ni}$ foil was exposed to an air at 400 and $600{ }^{\circ} \mathrm{C}$ for $12 \mathrm{~h}$ to make $\mathrm{NiO}$ on the surface of the $\mathrm{Ni}$ foil. The resulting $\mathrm{Ni}$ foil was analyzed by X-ray diffraction (XRD) and FTIR spectroscopy. It was observed that both $\mathrm{Ni}$ and $\mathrm{NiO}$ coexist at $600{ }^{\circ} \mathrm{C}$. So, partially oxidized Ni powders were prepared by heating Ni powders under air atmosphere at $600{ }^{\circ} \mathrm{C}$ for $12 \mathrm{~h}$.

Yttria-stabilized zirconia (YSZ) tube (Friatec AG, Germany) was used as a ceramic membrane with oxygen-ion conductivity. The tube (200 $\mathrm{mm}$ long and $5 \mathrm{~mm}$ in inside diameter with a wall thickness of $1.5 \mathrm{~mm}$ ) was stabilized with $8.5 \mathrm{wt} \% \mathrm{Y}_{2} \mathrm{O}_{3}$. The partially oxidized Ni powders as internal reference elements were placed at the bottom part of YSZ tube. For insulation and sealing, the rest part of the YSZ tube was sequentially filled with zirconia sand, ceramic sealant and expoxy adhesive (Fig. 3a). Finally, the $\mathrm{pH}$ sensing electrode was assembled using stainless steel fittings and epoxy adhesives for installation in the oncethrough loop system, as shown in Fig. 3b. The $\mathrm{pH}$ measurement system consisted of a $\mathrm{pH}$ electrode and an external $\mathrm{Ag} / \mathrm{AgCl}$ reference electrode. In general, the activation step is needed for the normal operation of the $\mathrm{pH}$ sensor. For this, the $\mathrm{pH}$ sensor was heat-treated in distilled water at $300{ }^{\circ} \mathrm{C}$ for 3 days.

The viability of the $\mathrm{pH}$ sensor developed in this study was assessed in synthetic coolant solution of $1 \sim 3$ ppm-Li and 1000 ppm-B. $\mathrm{LiOH}$ (Aldrich) and $\mathrm{H}_{3} \mathrm{BO}_{3}$ (Aldrich) were used as the source of $\mathrm{Li}$ and $\mathrm{B}$, respectively. The $\mathrm{pH}$ of each solution was recorded every second for $1 \mathrm{~h}$. Generally, the fluctuation in $\mathrm{pH}$ values was less than $0.1 \mathrm{pH}$ units and the $\mathrm{pH}$ data reported here were the average of all $\mathrm{pH}$ values measured for $1 \mathrm{~h}$. Furthermore, the effect of trace elements on $\mathrm{pH}$ of coolant systems was checked at $280^{\circ} \mathrm{C} . \mathrm{Fe}\left(\mathrm{NO}_{3}\right)_{2}, \mathrm{Ni}\left(\mathrm{NO}_{3}\right)_{2}, \mathrm{Cr}\left(\mathrm{NO}_{3}\right)_{3}$ and $\mathrm{Zn}\left(\mathrm{NO}_{3}\right)_{2}$ were used as sources of trace elements. Electrochemical measurements were carried out at $120 \mathrm{~atm}$ and $280{ }^{\circ} \mathrm{C}$. The temperature of test solutions was controlled by a cartridge heater with Zircaloy cladding and monitored by thermocouple which was installed between $\mathrm{Ag} / \mathrm{AgCl}$ reference electrode and $\mathrm{pH}$ sensor. All potentials were measured using a Keithley electrometer (M6514) with a high input impedance of $200 \mathrm{~T} \Omega$ and were recorded by a data acquisition system.

\section{Results and Discussion}

Fig. 1 shows the schematic of the once-through loop system for $\mathrm{pH}$ measurement at high temperature. In case of stainless steel, when it was exposed to high-temperature solution, corrosion products are generated to make a change in solution $\mathrm{pH}$. For this reason, titanium metal with strong corrosion resistance was used in the high-temperature region exposed to test solutions in order to protect contamination of test solutions by corrosion products generated from the structural materials at high temperature and maintain the purity of solutions. To remove impurities in the loop system, the system was operated with distilled water at $300{ }^{\circ} \mathrm{C}$ for 3 days. After that, the chemical composition of distilled water passing through the loop system was analyzed by ICP-AES. Metallic elements except Ni were not detected. Only Ni was detected at a few ppb levels, indicating that the loop system was not affected at all by high-temperature corrosion.

ANi foil was oxidized under air atmosphere at the tempera-

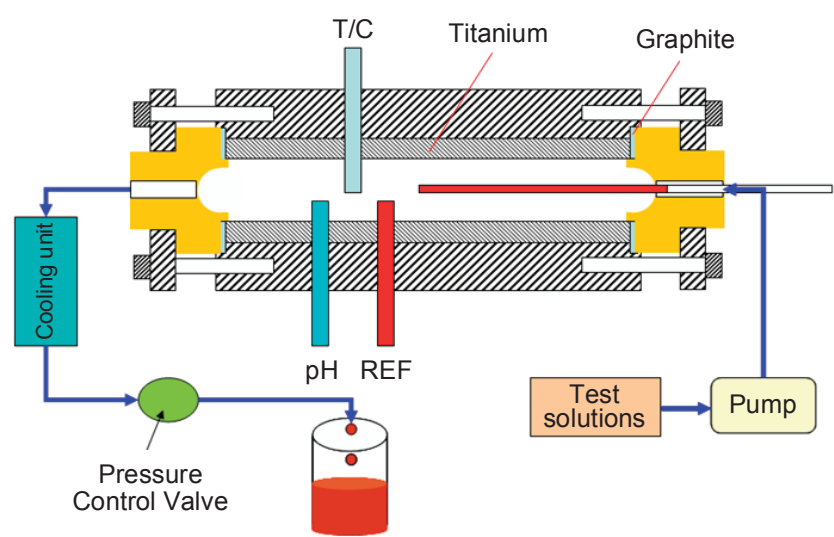

Figure 1. Schematic of the once-through loop system for $\mathrm{pH}$ measurement at high temperature.

(a)

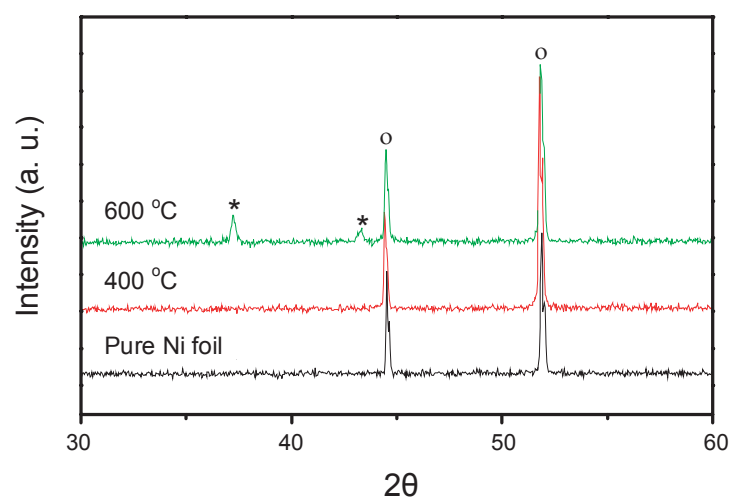

(b)

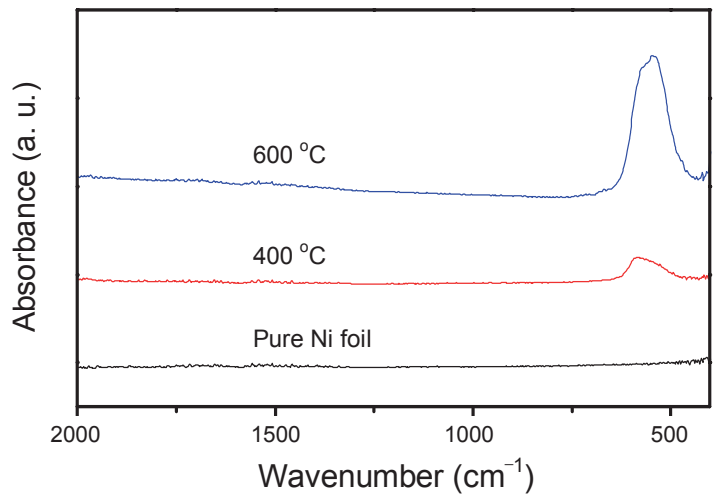

(c)

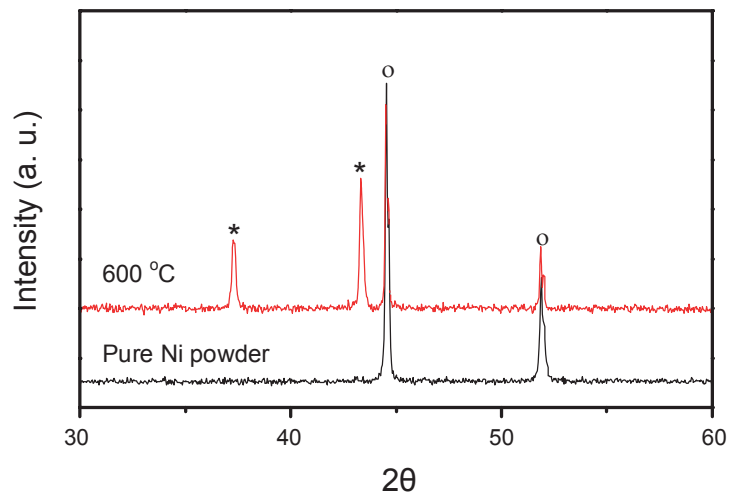

Figure 2. (a) XRD patterns of $\mathrm{Ni}$ foil and heat-treated Ni foils: Ni open circle and $\mathrm{NiO}$ asterisk; (b) FTIR spectra of Ni foil and heat-treated $\mathrm{Ni}$ foils; and (c) XRD patterns of Ni powders and heat-treated Ni powders: $\mathrm{Ni}$ open circle and $\mathrm{NiO}$ asterisk. 
ture of 400 and $600{ }^{\circ} \mathrm{C}$ to get a partially NiO-coated $\mathrm{Ni}$ foil so that both $\mathrm{Ni}$ and $\mathrm{NiO}$ exist simultaneously on the surface of the $\mathrm{Ni}$ foil. It was examined from XRD patterns that $\mathrm{NiO}$ did not form on $\mathrm{Ni}$ foil at $400{ }^{\circ} \mathrm{C}$ but well form at $600{ }^{\circ} \mathrm{C}$ (Fig. 2a). However, it was revealed from more surface-sensitive FTIR analysis that a small amount of $\mathrm{NiO}\left(450 \sim 600 \mathrm{~cm}^{-1}\right)$ could be produced even at $400{ }^{\circ} \mathrm{C}$ (Fig. 2b). So, Ni powders were oxidized at $600{ }^{\circ} \mathrm{C}$ to get $\mathrm{NiO}$-coated $\mathrm{Ni}$ powders $(\mathrm{Ni}-\mathrm{NiO})$ which would be used in $\mathrm{pH}$ sensors. Fig. $2 \mathrm{c}$ shows that $\mathrm{XRD}$ patterns of $\mathrm{Ni}$ powders heat-treated at $600{ }^{\circ} \mathrm{C}$ were similar to that of $\mathrm{Ni}$ foil, except intensity ratio of $\mathrm{NiO}$ to $\mathrm{Ni}$. $\mathrm{NiO}$ peaks of $\mathrm{Ni}$ powders were relatively more intense compared to those of $\mathrm{Ni}$ foil. It is thought that this can be attributed to the higher surface area of Ni powders.

$\mathrm{NiO}$-coated Ni powders were placed with a Pt wire current collector at the bottom part of YSZ membrane tube as shown in Fig. 3a. Above the internal reference system, quartz wool and $\mathrm{ZrO}_{2}$ sand were added. Finally, the rest of YSZ tube was filled with two kinds of sealing materials, ceramic sealant and epoxy, to completely seal the $\mathrm{pH}$ electrode. For easy installation in once-through loop system, the YSZ membrane was assembled using a home-made fitting method as shown in Fig. 3b.

For the electrochemical system, $\mathrm{Ni}-\mathrm{NiO} / \mathrm{YSZ}$ membrane $/ \mathrm{H}^{+}$, $\mathrm{H}_{2} \mathrm{O}$ (test solution), the operation principle of the $\mathrm{pH}$ sensor is based on the YSZ membrane that acts as an oxygen-ion conductor at temperature higher than $185^{\circ} \mathrm{C}$ and the following two kinds of reactions: chemical reaction at external interface of the membrane and electrode reaction at the internal interface of the membrane. ${ }^{9}$ The chemical equilibrium occurring outside YSZ membrane and electrode reaction inside YSZ membrane are expressed by equation 1 and equation 2 , respectively.

$$
\begin{aligned}
& 2 \mathrm{H}^{+}(\mathrm{aq})+\mathrm{O}^{2-}(\mathrm{YSZ}) \rightleftarrows \mathrm{H}_{2} \mathrm{O} \\
& \mathrm{NiO}+2 \mathrm{e}^{-} \rightleftarrows \mathrm{Ni}+\mathrm{O}^{2-}(\mathrm{YSZ})
\end{aligned}
$$

These equations mean that proton activity in solution side affects the oxygen ion vacancy within YSZ membrane and (a)

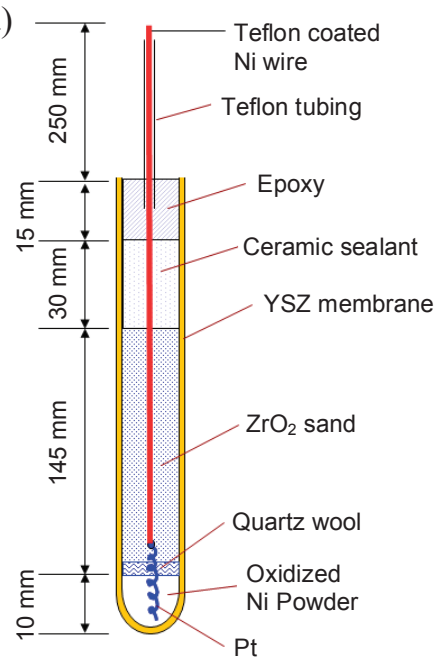

(b)

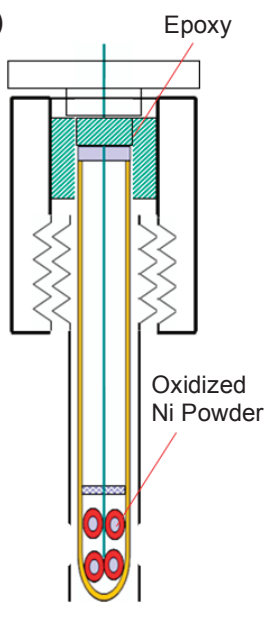

Figure 3. (a) YSZ-based $\mathrm{pH}$ sensor using partially oxidized Ni powders (Ni-NiO) and (b) pH sensor assembly with stainless steel fittings. finally the electrode reaction of $\mathrm{Ni} / \mathrm{NiO}$ redox couple.

As a result, overall reaction (eq. $1+$ eq. 2 ) is given by the following equation 3 :

$$
\mathrm{NiO}+2 \mathrm{H}^{+}(\mathrm{aq})+2 \mathrm{e}^{-} \rightleftarrows \mathrm{Ni}+\mathrm{H}_{2} \mathrm{O}
$$

From the overall reaction, potential $(E)$ measured at the $\mathrm{pH}$ sensor can be described as a function of $\mathrm{pH}$ by equation 4 .

$$
E(\mathrm{~T})=E_{\mathrm{Ni} / \mathrm{NiO}}^{\mathrm{o}}(\mathrm{T})-(2.303 \mathrm{RT} / \mathrm{F}) \mathrm{pH}
$$

where $E(\mathrm{~T})$ is the potential measured at a temperature T, $E_{\mathrm{Ni} / \mathrm{NiO}}^{\mathrm{i}}$ (T) is the standard potential for the $\mathrm{Ni} / \mathrm{NiO}$ redox couple at a temperature T, and, $F$ is Faraday constant.

To assess the viability of the new $\mathrm{pH}$ sensor, its performance tests were performed in the synthetic PWR primary coolants consisting of $\mathrm{LiOH}(1.0,2.0,3.0 \mathrm{ppm}-\mathrm{Li})$ and $\mathrm{H}_{3} \mathrm{BO}_{3}(1000$ ppm-B) at 120 atm and $280{ }^{\circ} \mathrm{C}$. Fig. 4 shows that the $\mathrm{pH}$ values measured by the $\mathrm{pH}$ sensor applying partially oxidized Ni powders as an internal reference system were very similar to theoretical values, implying that the $\mathrm{pH}$ sensor was successfully developed. It was observed that the measurement error by the $\mathrm{pH}$ sensor was less than $\pm 0.2 \mathrm{pH}$ units.

In addition, the effect of trace elements on $\mathrm{pH}$ of the synthetic coolants was investigated. Table 1 shows pHs measured in solutions of 3 ppm-M in synthetic coolants ( 3 ppm- $\mathrm{Li}+1000$ ppm-B) at $280{ }^{\circ} \mathrm{C}$, where $\mathrm{Fe}, \mathrm{Ni}, \mathrm{Cr}$ and $\mathrm{Zn}$ were used as $\mathrm{M}$. The concentration level of 3 ppm, which is 1000 times higher than the general concentration of corrosion products in a real

Table 1. The effect of trace elements on the $\mathrm{pH}$ of coolant solution at $280^{\circ} \mathrm{C}$.

\begin{tabular}{cc}
\hline Solution & $\mathrm{pH}$ \\
\hline 3 ppm-Li +1000 ppm-B & 7.05 \\
3 ppm-Fe +3 ppm-Li +1000 ppm-B & 6.93 \\
3 ppm-Ni +3 ppm-Li +1000 ppm-B & 6.79 \\
3 ppm-Zn +3 ppm-Li +1000 ppm-B & 6.90 \\
3 ppm-Cr +3 ppm-Li +1000 ppm-B & 6.99 \\
\hline
\end{tabular}

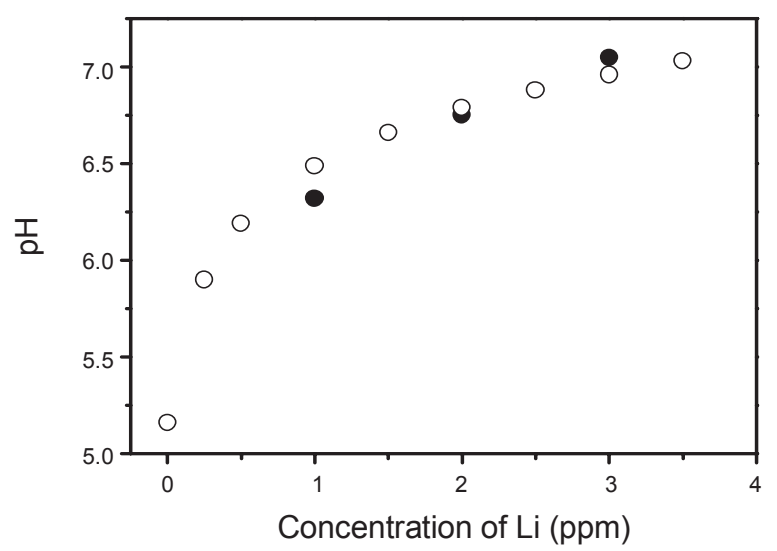

Figure 4. The $\mathrm{pH}$ values measured by the developed $\mathrm{pH}$ sensor in the synthetic coolant solutions consisting of $\mathrm{LiOH}(1.0,2.0,3.0 \mathrm{ppm}-\mathrm{Li})$ and $\mathrm{H}_{3} \mathrm{BO}_{3}(1000 \mathrm{ppm}-\mathrm{B})$ at $280^{\circ} \mathrm{C}$ : the measured values filled circle and the theoretical values open circle. 
primary coolant system, was used to observe an obvious $\mathrm{pH}$ change. It was found that coolants $\mathrm{pH}$ slightly decreased from 7.05 to 6.79 . This result suggests that the corrosion products at a real primary circuit have little influence on the $\mathrm{pH}$ of coolant, because their concentration is as low as a few ppb.

\section{Conclusions}

A new YSZ membrane-based $\mathrm{pH}$ sensor has been successfully fabricated by using partially oxidized Ni powders as an internal reference system instead of the conventional internal reference system, a mixture of $\mathrm{Ni}$ and $\mathrm{NiO}$. For making the partially oxidized Ni particles, study on the oxidation of $\mathrm{Ni}$ foil was carried out to determine an appropriate oxidation temperature. It was found from X-ray diffraction (XRD) and FTIR spectroscopy that $\mathrm{Ni}$ and $\mathrm{NiO}$ exist simultaneously on the surface of Ni particles, when they were heat-treated under air atmosphere at $600{ }^{\circ} \mathrm{C}$. The performance of the $\mathrm{pH}$ sensor developed was examined in the synthetic coolants $(1 \sim 3$ ppm-Li +1000 ppm-B) at $280{ }^{\circ} \mathrm{C}$. The $\mathrm{pH}$ sensor showed excellent accuracy with a small error less than $\pm 0.2 \mathrm{pH}$ units. In addition, the effect of trace metal elements on the $\mathrm{pH}$ of coolant solutions was investigated in solutions consisting of 3 ppm-M, 3 ppm-Li, and $1000 \mathrm{ppm}-\mathrm{B}$ at $280^{\circ} \mathrm{C}$, where $\mathrm{Fe}, \mathrm{Ni}, \mathrm{Cr}$ and $\mathrm{Zn}$ were used as $\mathrm{M}$. It was found that coolants $\mathrm{pH}$ slightly decreased from 7.05 to 6.79 , suggesting that corrosion products at a real primary cir- cuit have little influence on the $\mathrm{pH}$ of coolant, because their concentration is as low as a few ppb.

Acknowledgments. This work was supported by the nuclear R\&D program through the National Research Foundation of Korea funded by the Ministry of Education, Science and Technology.

\section{References}

1. Macdonald, D. D.; Butler, P.; Owen, D. Can. J. Chem. 1973, 51, 2590.

2. Tsuruta, T.; Macdonald, D. D. J. Electrochem. Soc. 1981, 128, 1199.

3. Macdonald, D. D.; Wentrcek, P. R.; Scott, A. C. J. Electrochem. Soc. 1980, 127, 1745.

4. Kriksunov, L. B.; Macdonald, D. D.; Millett, P. J. J. Electrochem. Soc. 1994, 141, 3002.

5. Macdonald, D. D.; Liu, J.; Lee, D. J. Appl. Electrochem. 2004, 34, 577.

6. Macdonald, D. D.; Hettiarachchi, S.; Lenhart, S. J. Solution. Chem. 1988, 17, 719 .

7. Niedrach, L. Science 1980, 207, 1200

8. Danielson, M. J.; Koski, O. H.; Meyers, J. J. Electrochem. Soc. 1985, 132, 296.

9. Lvov, S. N.; Zhou, X. Y.; Ulmer, G. C.; Barnes, H. L.; Macdonald, D. D.; Ulyanov, S. M.; Benning, L. G.; Grandstaff, D. E.; Manna, M.; Vicenzi, E. Chem. Geol. 2003, 198, 141 .

10. Eklund, K.; Lvov, S. N.; Macdonald, D. D. J. Electroanal. Chem. $1997,10,99$. 